\title{
Citizenship Studies: An Introduction
}

\author{
ENGIN F. ISIN and BRYAN S. TURNER
}

From aboriginal rights, women's rights, civil rights, and sexual rights for gays and lesbians to animal rights, language rights and disability rights, we have experienced in the past few decades a major trend in Western nation-states toward the formation of new claims for inclusion and belonging. More recently, this trend has echoed around the world from Zapatistas to Chechen and Kurdish nationalists, framing their struggles in the language of rights and recognition. While some, such as Michael Ignatieff, (2001) have dubbed these trends the 'rights revolution', the articulation of rights for various groups has been the most recurring theme of 'Western' political history: from ancient Greek and Roman peasants and plebeians to Italian artisans and French workers, articulating rights as claims to recognition has always invoked the ideal of citizenship. What has been happening in the past few decades then is neither revolutionary nor new but has been a recurrent, if not a fundamental, aspect of democratic or democratizing polities. What is new is the economic, social and cultural conditions that make possible the articulation of new claims and the content and form of these claims as citizenship rights. As such, these trends cannot be interpreted narrowly as 'minority rights' either as Will Kymlicka has (1995) argued. For these rights are articulated by distinct groups and cultures that belie the designation 'minority'. In the 1990s, citizenship studies emerged as an incipient field that took as its focus the conditions that make possible these new claims to citizenship rights and their dangers and promises not only in Western polities but across the world.

While citizenship studies is not yet an institutionalized field, it has established itself as a de facto field in the humanities and social sciences in the 1990s. The reasons behind the emergence of citizenship studies are no doubt associated with those broader conditions defined as 'postmodernization' and 'globalization' along with their concrete manifestations such as the reconfiguration of classes, the emergence of new international government regimes, new rationalities of government, new regimes of accumulation of different forms of capital, as well as new social movements and their struggles for recognition and redistribution. All these have forced upon academics, practitioners and activists alike an urgent need to rethink the political agent or subject under these transformations. Major social issues such as the status of immigrants, aboriginal peoples, refugees, diasporic groups, environmental injustices, and homelessness have increasingly been expressed through the language of rights and obligations, and hence of citizenship. Moreover, not only are the rights and obligations of citizens being 
redefined, but also what it means to be a citizen and which individuals and groups are enabled to possess such rights and obligations have become issues of concern. In other words, the three fundamental axes, extent (rules and norms of inclusion and exclusion), content (rights and responsibilities) and depth (thickness or thinness) of citizenship are being redefined and reconfigured.

The modern conception of citizenship as merely a status held under the authority of a state has been contested and broadened to include various political and social struggles of recognition and redistribution as instances of claim-making, and hence, by extension, of citizenship. As a result, various struggles based upon identity and difference (whether sexual, 'racial', 'ethnic', diasporic, ecological, technological, or cosmopolitan) have found new ways of articulating their claims as claims to citizenship understood not simply as a legal status but as political and social recognition and economic redistribution. Hence the increase in the number of scholars who work in feminist studies, queer studies, Aboriginal studies, African studies, diaspora studies, postcolonial studies, race and ethnic studies, urban studies, immigration studies, and environmental studies, who are exploring and addressing concepts of sexual citizenship, ecological citizenship, diasporic citizenship, differentiated citizenship, multicultural citizenship, cosmopolitan citizenship and Aboriginal citizenship. These studies, taken together, have already made an impact on social and political thought and practice in constitutional as well as governmental policies. Indeed, there has been a spectacular growth of the field of citizenship studies, evidenced in numerous books, ${ }^{1}$ articles, ${ }^{2}$ and theses ${ }^{3}$ dedicated to it.

All of these studies and initiatives suggest that the field is likely to expand in this decade. The scope of the field now certainly goes well beyond the mastery of any scholar. It is also a lively field, contesting and debating fundamental propositions of humanities and social sciences in important ways. It is by no means simplistic or optimistic to assume that in the next few years we shall observe the beginnings of new degrees, programs and specialties, establishing citizenship as a field of interdisciplinary studies in universities across the world.

Admittedly, a quantitative growth of a field cannot be taken as a measure of its academic quality or theoretical and practical impact. There is, however, growing evidence that citizenship studies is also making a major impact on our thinking about and practices of citizenship. The importance of accommodating some form of differentiated citizenship and the inadequacy of modern liberal citizenship are now widely accepted. As a result, it has been increasingly possible for various groups across the world to enact their claims to recognition and citizenship. Whether from common-sex partnership laws in Ontario or the rights of Kurds in Turkey, the modern, universal idea of citizenship has faced a significant challenge. Similarly, across the world many states have begun rethinking and revising their citizenship laws to recognize these growing demands. A revised German law now recognizes the rights of minorities and French laws recognize the rights of refugees: there is certainly a significant change taking place. This is the first volume that names the field as citizenship studies.

But all this does not mean that all is well and on a progressive path in citizenship studies or practices. There are enormous injustices, oppression and marginalization in 'democratic' as well as 'democratizing' states and the recognition of these injustices and their enactments of citizenship is anything but a straightforward struggle. While the Zapatistas marched through Mexico City, Chechens and Kurds are facing extermination. Citizenship studies is ultimately not about books and articles but about addressing injustices suffered by many peoples around the world, making these injustices appear in the public sphere, enabling these groups to articulate these injustices as claims for recognition and enacting them in national as well as transnational 
laws and practices, and thus bringing about fundamental changes. Citizenship studies is about producing analytical and theoretical tools with which to address these injustices with the depth, sensibility, scope and commitment that they demand and deserve.

Emerging from these studies and trends is a new conception of citizenship that challenges its modern variant. Modern citizenship itself was born of the nation-state in which certain rights and obligations were allocated to individuals under its authority. Modern citizenship rights that draw from the nation-state typically include civil (free speech and movement, the rule of law), political (voting, seeking electoral office) and social (welfare, unemployment insurance and health care) rights. The precise combination and depth of such rights vary from one state to another but a modern democratic state is expected to uphold a combination of citizenship rights and obligations. That said, however, three points must be borne in mind to avoid assuming citizenship rights and obligations as 'universal'. First, while within some states civil rights such as bodily control rights (medical and sexual control over the body) are guaranteed, some states deny even basic civil rights to its citizens, such as rights of access to courts and counsel. Similarly, while some states guarantee political rights and go so far as to franchise prisoners, others deny even such basic rights as refugee or naturalization rights. Citizenship obligations vary too, ranging from states where military service is required to those states where jury duty and taxes are the only responsibilities. Second, while many nation-states have elaborate rules and criteria for 'naturalization', the granting of citizenship to those not born in its territory, such rules and criteria are often contested and debated and vary widely. Third, even some basic citizenship rights are remarkably recent. We should remember that the property qualifications for citizenship were abolished as recently as, for example, 1901 in Australia, 1918 in Britain and 1920 in Canada. Even this should be interpreted cautiously as citizenship did not include Aboriginals in settler societies. Similarly, the franchise was extended to women as recently as 1902 in Australia, 1918 in Canada, and 1920 in the United States, while British women over the age of 21 have been able to vote only since 1928 and French women since 1944.

Thus, while cast in the language of inclusion, belonging and universalism, modern citizenship has systemically made certain groups strangers and outsiders. What determines the composition of citizens, strangers, and outsiders and their respective rights and obligations in a given nation-state depends on its historical trajectory. The typologies developed in citizenship studies to classify citizenship rights according to these trajectories are useful. For example, liberal, corporatist, and social democratic states, each of which rest upon a different interpretation of citizenship, can be identified. In liberal democracies such as the United States, Switzerland, and Australia, the state relies on markets to allocate social rights and emphasizes civil and political rights. In corporatist states such as Austria, France, Germany, and Italy, social rights are accorded a greater role but are not available universally. By contrast, in social democratic states such as Sweden, Norway, Finland, Denmark, and the Netherlands, social rights are given the highest priority and the state provides universal benefits such as the right to free vocational or higher education. There are, of course, states that do not neatly fit into these types. Canada, for example, combines a liberal emphasis on individual rights with a social democratic tradition of social rights, especially health and education. Britain also combines liberal and social democratic traditions.

Modern political theories about citizenship - liberalism, communitarianism, and republicanism - have grown out of these trajectories and roughly correspond to these three types of states. Liberalism puts a strong emphasis on the individual, and most rights involve liberties that adhere to each and every person. Concomitantly, communitarianism emphasizes the community 
(or the society or the nation), whose primary concern is with the cohesive and just functioning of society. Republican theories in both their conservative and radical variants put emphasis on both individual and group rights and emphasize the role of conflict and contest in the expansion or construction of such rights. Not all theories or theorists, however, neatly fit into these types. At any rate, in many democracies in the postwar era the debate and struggles over citizenship rights and obligations have been waged over either the expansion or the protection of rights. Most prominent have been the expansion of civil rights such as medical and sexual control over the body; political rights such as rights to naturalize, to aboriginal self-government or social movement or protest rights; and social rights such as old age pensions, unemployment insurance, health and education, job placement programs, affirmative action for minorities, collective bargaining, and wage earner and union investment funds. The protection of civil rights such as the rights of aliens to immigrate, political rights such as minority rights to equal and fair treatment, and social rights such as welfare or participation rights such as job security and workers' compensation have occupied governmental agendas. These debates and struggles have been mostly waged via the nation-state as both the source and appeal of authority.

While useful in the understanding of various theories and practices of citizenship rights and obligations across various postwar democratic states, these typologies and theories no longer capture the changing nature of citizenship in the twenty-first century. In the last two decades of the twentieth century, postmodernization and globalization challenged the nation-state as the sole source of authority of citizenship and democracy. Under these twin pressures, the blurred boundaries of citizenship rights and obligations and the forms of democracy associated with them brought citizenship on to the political and intellectual agenda, broadening the way in which citizenship is understood and debated. Rather than merely focusing on citizenship as legal rights, there is now agreement that citizenship must also be defined as a social process through which individuals and social groups engage in claiming, expanding or losing rights. Being politically engaged means practicing substantive citizenship, which in turn implies that members of a polity always struggle to shape its fate. Such developments have led to a sociologically informed definition of citizenship in which the emphasis is less on legal rules and more on norms, practices, meanings, and identities. Over the past several decades, the sheer mass of the academic literature on citizenship each year attests not only to the breadth of scholarly interest in it, but also to the extent that citizenship issues have become interwoven across academic disciplines. Citizenship studies is therefore decisively interdisciplinary.

There is no doubt that citizenship has also emerged as a major theme connecting policy domains that range from welfare, education, and labor markets to international relations and migration. Citizenship connects these because it brings within its orbit three fundamental issues: how the boundaries of membership within a polity and between polities should be defined (extent); how the benefits and burdens of membership should be allocated (content); and how the 'thickness' of identities of members should be comprehended and accommodated (depth). As a simple matter of law, nationality is the primary axis by which peoples are classified and distributed in polities across the globe. However, the continuing rise of new forms of cultural politics has challenged modern understandings of belonging and has contributed to rethinking the meaning of citizenship. The reality of immigration and emigration, the formation of such supranational and transnational bodies as the European Union (EU), the formation of new successor states, the movement of refugee populations, and the codification of international human rights norms has prompted increasing recognition of citizenship as a transnational matter. The growing incidence of plural nationality exemplifies the transnational dimension of 
citizenship not only as an object of policy but also increasingly as a source and marker of social identity. The difficulty in this growing recognition is that it has arisen through the interaction of citizenship rules that states, acting as sovereign agents, have adopted, but whose effects reach into the domestic jurisdictions of other states and invest individuals with binding affiliations to two or more states. This difficulty is compounded for nations that have seen themselves as ethnically or racially homogenous. Moreover, the increasing importance of cities in organizing and shaping cultural, social, symbolics, and economic flows has also prompted a recognition of their role in fostering citizenship. Thus, the sovereign state is no longer the only locus of citizenship. Yet very few citizenship laws are enacted either above or below national levels (e.g. EU). So while negotiations for citizenship take place above and below the state, laws are still enacted at national levels. Hence national trajectories and practices still constitute important issues in citizenship studies despite the fact that citizenship is now negotiated at a variety of levels and sites.

This is one of the reasons why multinational and settler societies such as Canada and Australia are watched with increasing interest by other nations as regards citizenship laws. Yet, as multinational and settler societies themselves struggle with issues of cultural recognition and multicultural citizenship, whether concerning the rights of immigrants or Aboriginal peoples, or separatism, many academics and policy-makers are surprised to discover that nations such as Germany, France, Britain, and those in Eastern Europe are keen to understand how such multinational states struggle with these issues. This is more than a paradox. For the questions that face the multinational and settler societies have now become (due to globalization and postmodernization) the questions that face states that originally saw themselves as ethnically homogenous, such as France, Germany, and even Japan. It has become increasingly difficult to imagine these nations as ethnically homogenous and racially pure.
What then of the future of citizenship studies? To put it starkly, there is neither a singular way of engaging with citizenship studies nor a singular way of investigating its objects. In fact, it is this dispersed discursive aspect that provides its vitality and liveliness, rather than an orthodox set of rules that govern conduct. Citizenship studies also embodies a potential to channel energies in various disciplines that focus upon social justice into a renewed focus with a vigor and robustness that so far have eluded 'postmodernized' and 'globalized' social sciences and humanities. As this introductory chapter has shown, there are many dimensions to the contemporary debate about citizenship and otherness, and we can predict that the evolution of citizenship theory will be equally complex, but we conclude with three issues that strike us as urgent. We will structure this discussion around the problem of national citizenship in relation to human rights, the question of the obligations and virtues of the citizen, and finally the problem of globalization and territoriality.

The first is the obvious problem of the historical connection between citizenship, nationalism and the nation-state. It has been frequently recorded that 'citizenship' (citeseyn, cite/sein/zein) is historically and etymologically connected to the city and then to the state. The citizen was originally a person who, by living in the city, participated in a process of cultivation or civilization. While the pagans lived in the countryside, the man of the city acquired both rights and culture. Citizenship was thus an exclusionary category. This is a generic problem, since that which includes must by definition exclude. But the historical connection has always been made from the perspective of not the excluded (strangers, outsiders, aliens) but the included (citizens). Following the Treaty of Westphalia and the creation of an international system of states, urban citizenship further developed as a basic foundation of the emergence of powerful nation-states. With the development of advanced administrative structures of the 
system of national governance, the state was able to mobilize citizenship as an aspect of nationalism. The state and citizenship became necessarily combined to form effective technologies of government.

Classical political philosophy and political economy also recognized the connections between citizenship and civil society. Hegel, while employing 'citizen' to mean a member of the state, recognized the associations between citizenship and civil society. In twelfth-century Europe, a burgher was a town-dweller, and in France bourgeois came to designate a stratum that was separate from the clergy and the nobility, but was also connected with 'market town'. Thus with the development of 'civil society' (bürgerliche Gesellschaft), there was an intimate set of interconnections between the bourgeoisie as a class, the creation of an autonomous civil society and citizenship. These cultural and social connections with urban middle class life were the origin of Marx's criticisms of citizenship. Using the emancipation of the Jews as an example, Marx argued that bourgeois citizenship made an artificial separation between politics and society, condemned the continuity of class inequality in liberal capitalism, and claimed that citizenship was a smoke screen that masked economic exploitation. Radical thinkers have often remained suspicious about the democratic thrust of citizenship rights and argued theoretically that the task of democratic politics was to restore the vitality of civil society.

While there is much substance to this claim, it is partial. The liberal theory of citizenship that emphasizes individual rights is only one version of citizenship theory. Historically the working class has often mobilized behind the discourse of citizenship to claim collective social rights, and citizenship as a set of institutions does not necessarily separate social and economic rights. On the contrary, the thrust behind modern citizenship has been to create a welfare state to achieve equality between citizens. Thus, the task of rebuilding civil society (or a public sphere) cannot be achieved without dynamic forms of citizenship.
Nevertheless, there has been a strong connection between citizenship and nationstate formation as sociologists such as Reinhard Bendix (1964) recognized. In the nineteenth century Citizenship became a platform for racial exclusion and a foundation for 'national manhood'. In the twentieth century, it has often been intimately connected with the construction and maintenance of a global labour market of 'guests and aliens' as Saskia Sassen has demonstrated. If Marx was concerned about the tensions between political and social rights, we should be exercised by the problem of citizen and human rights.

Precisely because citizenship rights have been historically tied to the nation-state, it is often thought that the rights of aboriginal and native groups, stateless people, refugees and children may be better served by human than by social (citizenship) rights. Aboriginal rights against postcolonial states are the typical example. In Australia, the doctrine of terra nullius meant that after 1788 the Aborigines became invisible and were treated as de facto migrants who could only claim rights as aliens. In the twentieth century, international legal institutions were often pitted against the state under the banner of human rights legislation to protect the rights of people who were not covered by a state. Similarly, people who were in conflict with a nation-state which they did not recognize as having legal jurisdiction would often appeal to human rights as a form of protection. For example, the British government has been frequently embarrassed by human rights criticism of its actions in Northern Ireland against the IRA and other nationalist groups.

Although human rights and social rights often appear to be in conflict from a legal standpoint, in practice people typically claim human rights from the basis of a pre-existing or articulable citizenship right. Northern Irish oppositional groups who question the legality of the actions of the British state in Northern Ireland are already citizens. The problem with human rights has been historically that they cannot be (easily) 
enforced, because there is no political community to which they can refer or which they can mobilize. In the absence of a global state with legitimate juridical powers around the world that can over-ride state legislation, it is difficult to see how human rights legislation can have authority over the legal rights of citizens of legitimate states. The problem is in short that human rights are often not enforceable or in more technical terminology are not 'justiciable'. In more specific terms still, while some jurists would accept the notion that political rights could be enforced, the whole arena of the social and cultural rights of the UN charters is not justiciable. So human rights are rarely conceptualized in terms of a set of corresponding obligations, and therefore there is some doubt about whether human rights are rights at all, as Giorgio Agamben (1993) suggested. Critics might conclude that citizenship rights are distinct and justiciable, but human rights are vague, unenforceable, quasi-rights. We do not accept this bleak conclusion and would argue that, for the foreseeable future, human and social rights are more likely to be compatible than mutually exclusive. Where citizenship rights fail to provide protection of individuals from the state, the individuals will appeal to international courts for protection of human rights. While we anticipate that the enforceable domain of human rights will increase with globalization, there are clearly tensions between national and international courts, and between citizenship and human rights.

Secondly, in modern times citizenship has often been an important component of social movements to expand social rights. The development of social rights through the women's movement, the peace movement and the Civil Rights movement in the United States are classic examples. Citizenship, rather than a strategy exclusive to the 'ruling class' as Michael Mann (1987) argued, has in contemporary politics emerged as fundamental to rights discourse and to oppositional movements. Recent debates about environmental citizenship and sexual citizenship have served to reinforce the assumption that citizenship is a collection of rights. The notion that citizenship might entail obligations has strategically been appropriated by right-wing governments who wish to use citizen charters as techniques for regulating public utilities. Thus in Britain various conservative governments became interested in the idea of citizenship both as obligations to the state and community, and as rights to adequate service from public utilities such as the railways. There is of course a much more radical notion of citizenship obligation associated with the idea of virtue.

While 'virtue' had become unfashionable in mainstream political science, it has been revived in contemporary political and sociological theory by writers like Alasdair MacIntyre (1981) and Martha Nussbaum (2001). In this respect there is an important division between liberal (Anglo-American) and cultural (continental) theories of citizenship. The liberal theory is minimalist. It purports that the role of the state is to protect the freedom of its citizens and that it can best achieve this aim by removing the obstacles to free exchange between individuals in the market place. The role of the state is utilitarian, namely to maximize the happiness of the majority, but this 'happiness' is most effectively and efficiently measured by their individual wealth. Because for writers like Jeremy Bentham and J.S. Mill, push-pin is as good as poetry (that is, they are equal because they both produce happiness), it is not sensible for states to take much interest in culture. With the dominance of neo-liberalism in state policy since the 1970s, the liberal view of citizenship has been triumphant. The alternative view is associated with the classical Greek polis, with Rousseau, and with the cultural legacy of the German Bildungsroman. This tradition says that the education of the citizen in the virtues is essential if that individual is to achieve personal autonomy. There is a fundamental difference between these two conceptions of autonomy. While neo-liberals have argued that the citizen needs training in order to secure a job in the labor market, virtue ethics argues that a person requires 
education in order to become an individual. The politics of virtue has a thick rather than thin view of the citizen of a nation, namely of the citizen as a complex, educated and vibrant member of a society. There is therefore an important connection between virtuous citizens and effective and living institutions; this connection is through the dual operation of virtue and obligation. An autonomous citizen will want to be an active and involved participant in a community.

We would argue that the neo-liberal view of citizenship is in crisis. Participation in the market is obviously important and the idea of the worker-citizen has been a foundational aspect of modern society. However, there are clearly problems with this foundation, especially where there is profound casualization of labor, under-employment, early retirement and flexible hours of work. As Richard Sennett (1998) has argued, the modern market creates casualized employment that leads to a 'corrosion' of character. There has also been a widespread devaluation of education and the university system by neo-liberal governments that have reduced funding and attempted to destroy the autonomy of universities in providing an education that is not merely training for a job. The marginalization of the worker and the degradation of education has resulted in an erosion of citizenship that we can see manifested in low participation rates in elections, distrust of politicians, lack of social capital investment in society, the decline of the public sphere, and the decline of the universities.

The third issue concerns the place of citizenship in the dynamic relationships between region, state, and global society in the modern world. The notion that there could be a 'citizen of the world' has long been part of the utopian imaginary of the citizenship tradition. It was implicit in Augustine's idea of the City of God within which the legacy of Roman global society would be perfected. It was part of Kant's vision of a 'perpetual peace' in which the Enlightenment dream of a world free from irrational prejudice could be realized. It was part of Goethe's idea of world society that would transcend the narrow limitations of emerging German militarism. Despite his criticisms of bourgeois citizenship, Marx dreamt of creating an international movement in which workers would unite to overcome capitalism, to transform human nature, and to establish a world polity. In recent years, this dream has re-emerged in the idea that globalization will demand or make possible world governance within which cosmopolitan democracy can flourish.

The revival of cosmopolitan idealism is in fact closely connected with the classical idea of virtue. There is a republican tradition that had its origins in the Stoical tradition of Rome that promoted the idea of cosmopolitan virtue. This tradition in the modern period has attempted to distinguish between love of country (patriotism) and respect for the state (nationalism). We have lost this tradition, failing typically to recognize any distinction between patriotic and nationalist commitments. Writers such as Giuseppe Mazzini (1906) argued that love of one's own country was perfectly compatible with commitment to a commonwealth that embraced a love of humanity. Indeed an education in the love of patria moved inevitably towards a commitment to the respublica. This language of virtue and the commonwealth has been lost to us in a world that has become dominated by calculating rationalism and the neo-liberal faith that our private vices (greed) are public virtues (wealth).

Statecraft today is concerned with wealth creation not value creation, but the language of patria and pietas need not be archaic. Indeed, if we are to have global rights and cosmopolitan citizenship, we need to evolve a language of obligation and virtue. What commitments might a cosmopolitan citizen have? We suggest that one answer would be respect for other cultures and that this commitment to protect the cultural multiplicity of the global commonwealth would constitute a cosmopolitan virtue. We detect elements of this development in the theory of cosmopolitan democracy that has been promoted by writers such as David Held (1995). 
Often the contemporary celebration of globalization neglects previous historical examples of globalism and cosmopolitanism such as Greek and Roman civilization, various world religions including Islam, the ecumenical aspects of Christianity, the Enlightenment, and socialism. Unless we have a clear view of how other cultures have experienced globalization prior to modernity we will fall deeply into the trap of previous forms of orientalism. Any discussion of cosmopolitan citizenship must overcome orientalism.

Various trends and dimensions of the current debate point in the direction of cosmopolitan or global citizenship. One such example might be Aihwa Ong's idea (1999) of flexible citizenship which she has developed in her work on the Chinese diasporic élite, but this perspective could in principle apply to all diasporas. As the globalization process produces multiple diasporas, we can expect very complex relationships between homeland and host societies that will make the traditional idea of national citizenship increasingly problematic. The increasing rates of labour migration and the growth of dual citizenship arrangements indicate that citizenship itself will become differentiated to accommodate these new status positions and identities. These labor and other migratory movements will produce a variety of interconnected social changes that are associated with multiculturalism in terms of marriage, family structures, pluralism, and multiplicity. The politics of difference and identity attempts to address these cultural transformations, and this transformation of societies places new demands on traditional or national patterns of citizenship. The European Union has been attempting to address these questions through changes to citizenship status that as a minimum give some recognition to resident workers, for example Turks in Germany, who do not have full citizenship membership but nevertheless have rights by virtue of their presence as social groups.

In short, as societies are forced to manage cultural difference and associated tensions and conflict, there will be necessarily significant changes in the processes by which states allocate citizenship and a differentiation of the category of citizen. At a deeper level, these patterns of cultural multiplicity and identity raise questions about the porosity of political boundaries and cultural borders. Does a modern democracy require a strong sense of territorial integrity or can democracies evolve with very open and porous boundaries? There are many different answers to this question, but in terms of the republican legacy of patriotism, love of country prepares the way to respect for strangers and outsiders. Cosmopolitan openness might be compatible with a strong sense of place and tradition, provided there is a recognition of difference and otherness. This vision may appear utopian, but it is an important normative position from which to challenge the negative and closed features of nationalism, racism and fundamentalism. Citizenship must be a central component to whatever answers and policies emerge towards global governance.

\section{NOTES}

1 While citizenship studies is a young and contested field, already there are literally hundreds of books and thousands of articles spanning all disciplines in humanities and social sciences. As of 2001, a search in Canada's largest research library, Robarts, yielded more than 2,600 books, manuscripts and reports mentioning citizenship. Of these, 976 included citizenship specifically in their subject keywords, a vast majority of which were published in the 1990s. Of these 2,600, more than 900 specifically included 'citizenship' in their titles, which is a much stronger measure of their affiliation with the field. Of these 900, 37 were published in 2000, 38 in 1999, 57 in 1998, 49 in 1997, 45 in 1996, 35 in 1995, 32 in 1994, 42 in 1993, 36 in 1992, 16 in 1991, and 14 in 1990. Clearly, the 1990s was a decade of significant growth in books published in citizenship studies, with an upward trend toward the end of the decade. That nearly $50 \%$ of all books in citizenship studies were published in only one decade is remarkable.

2 While since 1997 Citizenship Studies has been amongst the most visible journals in the field, almost all journals in social sciences and humanities have published a significant amount of work in the last decade on 
citizenship. As of 2001, a research on the journal indexes available on WebSPIRS database yielded interesting results. A search on the Social Sciences Index alone yielded more than 1,100 articles citing citizenship, more than 500 of which directly addressing citizenship in their subject keywords. A similar search in the Humanities Index yielded more than 200 articles, more than 100 of which specifically addressed citizenship in their subject keywords. Historical Abstracts alone yielded 1,170 articles in major world languages specifically using citizenship in their subject keywords. Also in Historical Abstracts, a search on title using 'citizens' or 'citizenship' yielded 696 articles in major world languages. The same searches restricted to English-language articles yield 725 and 403 articles respectively. A search on citizenship in Social Science Citation Index, provided by Web of Science, yielded 2,723 articles published since 1970 in English alone focusing on citizenship. Of these, 2,409 used a variant of 'citizenship' in their titles. The Index also listed 863 reviews of books on citizenship.

3 The Dissertation Abstracts Index, which covers the majority of North American theses, lists more than 1,000 theses in the 1990s with relevance to some aspect of citizenship studies, nearly 300 of which were specifically about citizenship. More than 150 of these theses included 'citizenship' in their titles. More specialized disciplines such as law also yield important results. The Index to Canadian Legal Literature for example yielded more than 1,100 articles specifically addressing the issue of citizenship in their subject keywords. More impressively, a search on the PAIS International Index yielded more than 500 items specifically containing citizenship in their subject keywords. The PAIS International database is a bibliographic index to the literature of public policy, social policy, and the social sciences in general and includes journal articles, books, government documents, statistical compilations, committee reports, directories, serials, reports of public, intergovernmental, and private organizations, and most other forms of printed literature from all over the world. PAIS therefore is a good index of 'discursive' interest in a topic ranging from academic to governmental and professional literatures.

\section{REFERENCES}

Bendix, R. (1964) Nation-Building and Citizenship: studies of our changing world. New York: Wiley.

Held, D. (1995) Democracy and the Global Order: from the modern state to cosmopolitan governance. Cambridge: Polity Press.

Ignatieff, M. (2001) Human Rights as Politics and Idolatry. Princeton and Oxford: Princeton University Press.

Kymlicka, W. (1995) Multicultural Citizenship A Liberal Theory of Rights. Oxford: Clarendon Press.

MacIntyre, A. (1981) After Virtue. South Bend: University of Notre Dame Press.

Mann, M. (1987) 'Ruling class strategies and citizenship' Sociology, 21(3): 339-54.

Mazzini, G. (1906) Dell'amor patrio di Dante in Scritti editi e inediti ai Giuseppe Mazzini. Imola.

Nussbaum, M.C. (2001) The Fragility of Goodness. Luck and Ethics in Greek Tragedy and Philosophy. Cambridge: Cambridge University Press.

Org, A. (1999) Flexible Citizenship. The Culturial Logics of Transnationality. Durham and London: Duke University.

Sassen, S. (1999) Guests and Alicns. New York: The New Press.

Sennett, R. (1998) The Corrosion of Character. The Personel Consequences of Work in the New Capitalism, New York: W.W. Norton. 